\title{
Research on Traditional Ecological History Experience in Site Selection of Hexia Ancient Town
}

\author{
Tianchi Wang, Xingyu Ma \\ Huaiyin Institute of Technology, Huai'an, China \\ Email: 330134539@qq.com, 13675374@qq.com
}

How to cite this paper: Wang, T. C., \& Ma, X. Y. (2020). Research on Traditional Ecological History Experience in Site Selection of Hexia Ancient Town. Open Journal of Social Sciences, 8, 271-278. https://doi.org/10.4236/jss.2020.812021

Received: November 20, 2020

Accepted: December 19, 2020

Published: December 22, 2020

Copyright $\odot 2020$ by author(s) and Scientific Research Publishing Inc. This work is licensed under the Creative Commons Attribution International License (CC BY 4.0).

http://creativecommons.org/licenses/by/4.0/

\begin{abstract}
A series of regional historical ecological experiences came out with the development of Chinese ancient town on the guidance of simple ecological concept during the past thousands of years. These experiences through long-term practice demonstration, simply done, embody the harmony between man and the environment. This paper taking Huai'an Hexia ancient town as an example, analyzes its unique construction strategy of the urban form and layout in this area affected by the Grand Canal, considering local cultural background and natural conditions. This study can provide some references for modern town planning.
\end{abstract}

\section{Keywords}

Hexia, Town Planning, Ecology, Historical Experiences, The Grand Canal

\section{Introduction}

At the ancient time, the development of traditional towns has their own internal drive. In particular, how Chinese traditional towns were selected and built without the guidance of modern planning theory was influenced by simple ecological thinking. This article attempts to explore the relevant experience in the site selection and planning of traditional towns through the study of Hexia ancient town in Huai'an, and provides some theoretical basis for the study of the evolution of traditional towns.

Since the middle of the last century, the rapid increase in human development has made people aware of the destruction of the natural ecological environment by a series of actions. How to achieve sustainable development through energy saving and emission reduction has become an important strategy for social de- 
velopment today.

During the development period of ancient Chinese farming culture, under the influence of simple ecological thinking, people formed a set of their own traditional village and town construction system after summing up their life experience for a long time. These strategies are simple and easy to implement, have strong regional characteristics, conform to the laws of long-term life and production development of local people, and can effectively improve the living and living environment of local residents and improve their comfort. Therefore, the study of the ecological and historical experience of traditional villages and towns planning can help us find out the regional measures of today's village and town construction planning and realize the sustainable development of human settlements in this area. Taking the ancient town under the Huai'an River as an example, this article discusses a series of ecological and historical experiences in the site selection and planning of this area that were affected by the canal and other water system factors during the traditional construction process.

\section{Background Overview of Hexia Town}

Hexia is located in Huai'an District (Figure 1), Huai'an City, Jiangsu Province, close to the Grand Canal. It has a long history and was an important connection between Huai'an City and the canal in the old days. During the Ming and Qing Dynasties, with the prosperity of canal water transport, the ancient town of Hexia, a historical town that "supposed the north and south" (Xun, 1999), relied on the favorable terrain of the Grand Canal and the ancient city of Huai'an as the seat of the "Governor of Water Transport" (Jia, 2010). It developed rapidly and reached its peak. This area is a region with hot summers and cold winters, with a semi-humid monsoon climate in the northern temperate zone. Affected by the monsoon climate, the four seasons here are distinct, with concentrated rainfall, rain and heat in the same season, cold in winter and hot in summer, variable temperature in spring, high air in autumn, sufficient light energy and abundant heat.

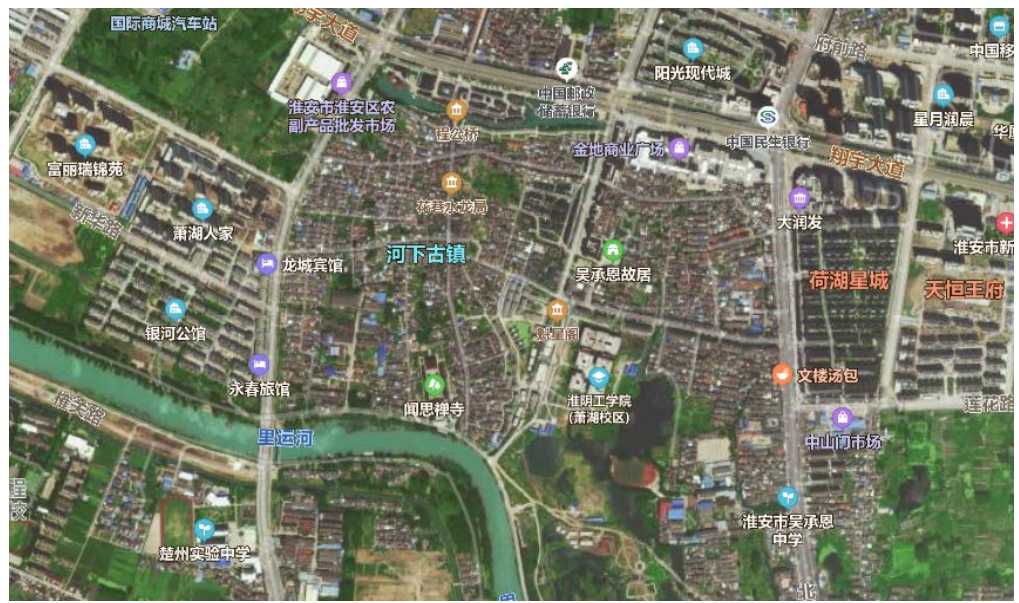

Figure 1. The location of Hexia town. Image Source from Baidu map, edited by author. 
The unique natural and humanistic conditions of Hexia promoted the unique settlement patterns and architectural layout of the ancient town.

\section{Analysis of Ecological Factors in Site Selection of Ancient Town}

The book "Ecological Architecture" puts forward that "the key to ecological site selection is to analyze and evaluate the various advantages and disadvantages of the base site. During the analysis and evaluation, the content can be divided into natural environment and social environment. Natural environment includes geology, landforms, hydrology, and climate. The social environment refers to the environment caused by human factors, social, economic and other influencing factors. They will affect the development and utilization, spatial form, municipal facilities, etc., as well as the investment benefits of construction, the adoption of engineering measures, and the speed of construction." (Ran \& Liu, 2008)

The surrounding water system of Hexia Town is well developed. The water network system not only provided a good natural ecological environment for the formation of Hexia Town, but also laid an important social foundation for its development. Compared with the construction of cities with higher traditional organizational levels, the location and development of villages and towns are more spontaneous, and continue to grow, which can better reflect the impact of the surrounding environment. Hexia, which is close to the Beijing-Hangzhou Canal, is also affected by the natural and human factors of the canal water system.

\subsection{Natural Factors}

The development of urban construction in ancient China has a long history. This kind of planning model is a kind of experience summary formed by the Chinese people after thousands of years of long-term practice (Li, 1998). It emphasizes the harmonious coexistence of man and nature and pursues the coexistence of heaven, earth and nature. It is a simple ecological theory.

China is in the monsoon climate zone of the northern hemisphere. "Sitting at the foot of the mountain and facing the water" can withstand the cold wind from the north to the region. At the same time, the water system in the south can play a very important role in air convection and improve the regional climate (Bao, 2008).

Hexia is located in the central part of the Northern Jiangsu Plain and the northwestern part of the Lixiahe area. The terrain in the territory is relatively flat, with a slight slope from northwest to southeast, with an average height of 8 3 meters above sea level.

In such an environment, the "mountain" factor is greatly weakened, and people pay more attention to the use of "water".

Hexia relies on the establishment of the ancient Han ditch. The water system is developed in the area. It is adjacent to Xiao Lake in the east, Beijing-Hangzhou 
Grand Canal in the southwest, and Shi River to the north, as well as the Salt River, Wusha River, and Luoliu River and so on. From the 1908 water system map, we can see that there are still many trickles and lakes in the area, such as the Liuli River. The well-developed water network system not only provides a good life guarantee for the daily life of the people in the region, but also helps to adjust the microclimate in the region.

From an ecological point of view, water has a stronger ability to absorb microwaves than land, so water systems have better heat capacity than land (Chen, 2013). In summer, water can well absorb the heat emitted by the surrounding land and effectively reduce the temperature of the surrounding area; on the contrary, in winter, the water body can better store the heat brought by solar radiation during the day, and provide a certain amount for the surrounding area. The amount of heat radiation forms a small environment relying on this system.

At the same time, due to the existence of temperature difference, air convection is promoted and a natural air duct is formed, which has a very obvious regulating effect on the climate in a small area.

Therefore, Hexia was built next to the water, taking advantage of the characteristics of the water body in the site selection. In summer, the temperature of the water system such as the canal is lower than that of the land in the ancient town. The water body absorbs the thermal radiation from the land and forms convection to achieve the effect of cooling; winter water storage. The heat energy can be provided to the inland, thereby reducing the cold feeling brought by the cold air, and effectively using the natural ecological conditions to improve the air comfort in the area. The cold and hot convection also promotes the air conduction in the microclimate, and to a certain extent alleviates the uncomfortable feeling of summer hot.

\subsection{Social and Economic Factors}

The development of traditional productivity in ancient times was relatively slow, and people lacked advanced and fast means of transportation for commuting. The perfect water network system not only provides daily water for local residents, and brings sufficient water resources to the local farming economy, but also provides convenient transportation for the development of the urban economy in the region, which is conducive to the development of the regional urban form. The Beijing-Hangzhou Grand Canal, as an important route for north-south transportation in ancient times, had a series of positive effects on the development of Hexia Town.

\subsubsection{Water Transportation}

Convenient transportation conditions often drive the development of a region.

In ancient times, water transportation in eastern China helped the development of cities along the transportation, and the prosperity of water transportation caused great changes in the development of cities along the canal. Huai'an is located in the north of Jiangsu, at about the midpoint of the Grand Canal. All 
materials and food collected from the Yangtze River must pass through Huai'an. Therefore, during the Ming and Qing dynasties, the ancient city of Huai'an had a water transport governor.

The ancient city of Hexia lies one kilometer west of the ancient city of Huai'an, and it happens to be located between the ancient city and the waterway. Merchants from north to south often stay here. The river under the river supports the traditional farming mode and becomes an important commercial port in Huai'an, thus promoting the development of Hexia.

At the same time, looking at ancient and modern times, it is not difficult to find that important central cities tend to drive the rapid social and economic development of surrounding areas, and even form a series of satellite cities. The important social status of the ancient city of Huai'an formed by the canal in the Ming and Qing Dynasties also formed a strong political support for the development of Hexia.

\subsubsection{Salt Industry}

From the beginning of the Ming Dynasty, Huaibei salt farms had developed skills, so the Huaibei Salt Transport Branch was established in Hexia (Xu \& Miao, 2020). A large number of merchants lived here. The salt merchants in this period were mainly in Anhui, Yangzhou, Suzhou and other places (Huai'an Local History Studio, 2007). These areas had the development of architectural skills was quite mature in ancient times. When these salt merchants set up new homes in Hexia, they mostly used high-standard establishments. Therefore, they also brought the developed traditional construction techniques from various places, and to a large extent also promoted the formation and development of the entire ancient town's architecture and planning.

\subsubsection{Shipbuilding Industry}

In the Ming Dynasty, Sir Pingjiang Chen Xuan established the country's largest shipyard-Qingjiang Shipyard, located in Qingjiangpu, "between the two counties of Shanyang and Qinghe". It has become the largest shipbuilding center in the country. The well-developed shipbuilding industry has made the ancient town, Hexia, near the water system a distribution center for shipbuilding materials, attracting a large number of merchants. In today's Hexia Ancient Town, there are still Dingtie (Smith) Alley, Datong (Making Iron) Alley, Bamboo Alley, etc., which have a certain relationship with the shipbuilding industry at that time.

From this, we can find that the canal water system in the Ming and Qing Dynasties undertook multiple ecological functions such as water supply, shipping, politics, and culture, and it played a strong guiding role in the development of urban forms.

\subsubsection{Business}

Compared with the market in Huai'an City, the market in Hexia is more developed. There are still Huaxiang, Tea Alley, Gutong Alley, etc. in the town, indicating the occupational division of labor of local residents at that time. When the 
same types of industries are concentrated in one place, it reduces the waste of resources required for production and life, facilitates the management of towns, and plays a certain positive ecological significance. These and the old local bridges and rivers formed an intricate and overlapping organization system, which had an important impact on the layout of the ancient town.

\section{Ecological Analysis of the Layout of Hexia Ancient Town}

Traditional villages and towns, after selected by a suitable base site, continue to develop and expand to form a scale, and their layout and development context will also be affected by ecological factors.

The ancient town of Hexia is located in the Jianghuai Plain with four distinct seasons. It belongs to the transitional area from the north subtropical to the warm temperate zone, with significant monsoons. Affected by the wind direction and the water system on the entire area, the streets and lanes of the entire Hexia Ancient Town basically present a vertical and horizontal grid of intersecting north and south crosses. This network of streets and lanes uses a series of north-south streets to connect the two main water systems on the north and south sides of the ancient town with small tributaries. Combined with the dominant north-south wind direction, it promotes the exchange of energy between the water body and the land, which is beneficial to the entire ecological environment. However, unlike the land and water layout that often occurs in villages and towns in southern Jiangsu, land is still the main mode of transportation in the entire area. When the land meets the barrier of water, only some small road bridges are used to connect the roads. The water body has little influence on the layout of the entire village.

In ancient times, the Chinese people under the influence of traditional Confucianism had introverted personality traits and social relations with blood as the bond, making ancient villages and towns often present a chessboard layout with courtyards as the basic unit. This layout is conducive to air circulation in the city and is conducive to improving the urban environment. In addition, the vertical grid makes the utilization rate of the interior of the building high, while keeping the figure factor as small as possible (Zhu, 2019).

Comparing the street and lane scales of the first generation in southern Jiangsu and northern Zhejiang, it is not difficult to find that the cross-section of street containers in the Hexia area is wider and shorter than that in southern Jiangsu and northern Zhejiang. This is because the southern area has higher requirements for air convection, so as to be more conducive to taking away the excessive heat radiation in summer. At the same time, the larger the aspect ratio, the smaller the amount of direct heat radiation received by the streets and lanes, which has a certain buffer effect on the constant comfort of human settlements in southern Jiangsu and northern Zhejiang. And Yaowan (Sun \& Luo, 2016) in the northern part of Hexia Ancient Town has a smaller height-to-width ratio of streets and lanes than Hexia, which is also determined by the local climate. Therefore, we can conclude that, in the process of development, villages and 
towns always form a layout suitable for local natural conditions according to the requirements of local living comfort, which has its own uniqueness.

In addition, greening also has a good ecological significance in the layout. Unlike in modern cities, greening systems mostly appear in strong geometric forms, the distribution of traditional greening is more random. Greening in ancient towns often occurs at various nodes of the street network. While beautifying the environment, it forms shadow areas. Together with the transpiration of water absorbed by the roots of the plants themselves, it reduces direct sunlight and consumes a lot of heat on the ground, so as to achieve the effect of cooling. At the same time, there used to be a large number of private gardens under the river, with rich vegetation types, which also beautify and optimize the micro-environment of residential courtyards (Guo, 2018).

The public drainage system in the town is located under the streets. In the middle of the traditional streets under the river is a large block of granite slabs, and the two sides are paved with bricks. As the main arterial road, Huzui Street, the entire street is low in the middle and gradually rising on both sides. In this way, the rainwater is collected in the middle of the road in an organized manner, and then drained into the ditch under the stone slab through the drainage hole. The underground ditch is connected with the surrounding water system. Such a perfect circulation system solves the drainage problem of the building very well, which is convenient and effective. According to locals, the northern part of the entire Hexia area was originally an ancient Yellow River embankment, making the entire terrain present a natural topography from north to south from high to low, which facilitates the connection of the entire drainage system with the $\mathrm{Li}$ Canal.

\section{Conclusion}

It can be found through the study that the construction of traditional towns in ancient China has undergone thousands of years of continuous evolution and development, and has accumulated a series of ecological planning experiences with strong regional characteristics, which reflect the simple ecological philosophy theory, ecological planning theory and the initial formation of ecological economic consciousness. The site selection plan of Hexia ancient town of Huai'an combines the advantages of the social background derived from the canal in the area to select the base site, make full use of the surrounding favorable natural conditions, and adopt the most basic methods in a simple and effective way to use water bodies such as the Beijing-Hangzhou Grand Canal. In order to rely on it, give full play to its physical performance combined with the local climate characteristics, improve heat radiation, ventilation, waterproofing and other issues to improve the comfort of local human living. This kind of town location layout method does not rely on high-tech support but focuses on the organization of the site, the rational arrangement and design of the building group, and is more universally applicable to northern Jiangsu and even wider 
areas. The study of the ecological history experience in the site selection and planning of the ancient town of Hexia is helpful to provide reference for the planning and construction of today's towns and to provide help for the practice of improving the comfort of local residents and taking the route of sustainable development.

\section{Acknowledgements}

Sponsored by Project on "A Study on the Translation of Classical Texts of Traditional Buildings along the Canal in the Context of Jiangsu" under "2017 Jiangsu Province Social Science Application Research Excellent Project Foreign Language Project" (17jsyw-05).

\section{Conflicts of Interest}

The authors declare no conflicts of interest regarding the publication of this paper.

\section{References}

Bao, L. (2008). A Preliminary Study on the Construction Strategy of Traditional Jiangnan Buildings Adapted to the Climate. Architect, No. 4, 122-124.

Chen, R. (2013). Research on the Historical Experience of Water Ecology in the Planning of Traditional Villages and Towns in Southern Jiangsu. Jiangsu Urban Planning, No. 6, 56-61.

Guo, X. D. (2018). The Streets and Lanes of the Hexia Ancient Town in Huai'an. Anhui History, No. 11, 78-81.

Huai'an Local History Studio (2007). Guzhen Hexia. Local History Publishing House.

Jia, J. (2010). Analysis of Private Gardens in Hexia Town, Huaian Prefecture during Ming and Qing Dynasties. Journal of Chinese Architecture History.Third Series, 95-99.

Li, X. F. (1998). Adaptation and Symbiosis: The Ecological Development of Traditional Settlements. Huazhong Architecture, No. 2, 41-46.

Ran, M. Y., \& Liu, Y. (2008). Ecological Architecture. Wuhan: Huazhong University of Science and Technology Press.

Sun, Q. Y., \& Luo, Q. (2016). Research on the Development Strategy of Huai'an Waterfront Space from the Cultural Perspective: Taking the Ancient Town Section of the Liyunhe River as an Example. Modern City Studies, No. 2, 112-116.

$\mathrm{Xu}$, C. J., \& Miao, L. (2020). A Study on the Decorative Patterns of Traditional Houses in Hexia Ancient Town. Popular literature, No. 5, 16-19.

Xun, D. L. (1999). The Origin and Development of "Sanhuai City". Regional Research, 4, 23-25.

Zhu, W. W. (2019). The Ecological Wisdom and Enlightenment of Space Construction of Traditional Villages in Southwest China. Chongqing: Chongqing University. 